\title{
Quantitative variation for grain quality in Brazilian maize populations
}

\author{
Andréa Mittelmann ${ }^{1 *}$; José Branco de Miranda Filho²; Luciano Lourenço Nass ${ }^{3}$; Gustavo \\ Júlio Melo Monteiro de Lima ${ }^{4}$; Claudete Hara-Klein ${ }^{4}$; Ricardo Machado da Silva ${ }^{5}$ \\ ${ }^{1}$ Embrapa Gado de Leite, C.P. 403 - $96001-970$ - Pelotas, RS - Brasil. \\ ${ }^{2}$ USP/ESALQ - Depto. de Genética, C.P. 09 - 13418-900 - Piracicaba, SP - Brasil. \\ ${ }^{3}$ Embrapa Recursos Genéticos e Biotecnologia, C.P. 02372 - 70770-900 - Brasília, DF - Brasil. \\ ${ }_{5}^{4}$ Embrapa Suinos e Aves, C.P. 21 - 89700-000 - Concórdia, SC - Brasil. \\ 'Universidade de Taubaté - Depto. de Biologia, Av. Tiradentes, 500 - 12030-180 - Taubaté, SP - Brasil. \\ *Corresponding author < andream@cnpgl.embrapa.br>
}

\begin{abstract}
Development of maize (Zea mays L.) cultivars with high grain protein and oil concentrations and an appropriate amino acid composition, without losses in grain yield, represents a challenge in breeding programs. The objective of this work was to study the nutritional quality of ten Brazilian maize populations evaluated in three environments. A randomized block design with six replications was used. Ear yield and the concentrations of protein, oil, serine, glutamic acid, alanine, leucine, tyrosine and phenylalanine were evaluated. Individual and combined analyses of variance were performed. Populations diverged for most of the traits. Environmental effects influenced variation for most of the traits, unlike genotype-environment interaction, allowing the selection on the average of environments. Positive association exists among protein and most of the amino acids, when considered on a dry matter basis and there is no association between nutritional quality and yield; therefore, the development of cultivars that are superior for both traits is expected to be feasible. Key words: plant breeding, nutritional quality, protein, amino acids
\end{abstract}

\section{Variação quantitativa para qualidade de grãos em populações brasileiras de milho}

\begin{abstract}
RESUMO: O desenvolvimento de variedades de milho (Zea mays L.) com maiores teores de proteína e óleo nos grãos e um balanço adequado de aminoácidos, sem prejuízo do rendimento de grãos, representa um desafio para o melhoramento. Estudou-se a qualidade nutricional em dez populações brasileiras de milho. As populações foram avaliadas em três ambientes. Os experimentos foram realizados em delineamento de blocos casualizados com seis repetições. Foram avaliados o rendimento de espigas e as concentrações de proteína, óleo, serina, ácido glutâmico, alanina, leucina, tirosina e fenilalanina. Análises de variância por experimento e conjunta foram realizadas. Há variação entre populações para a maioria dos caracteres estudados. Há efeito de ambiente para a maioria dos caracteres, mas não da interação genótipo-ambiente, permitindo a seleção para a média dos ambientes. Existe uma associação positiva entre o teor de proteína e o da maioria dos aminoácidos quando considerados com base na matéria seca e não há associação entre a qualidade nutricional e o rendimento. Portanto, é possível o desenvolvimento de cultivares superiores para ambos os caracteres.

Palavras-chave: melhoramento, qualidade nutricional, proteína, aminoácidos
\end{abstract}

\section{Introduction}

Better biological use of maize (Zea mays L.) grain depends not only on the protein concentration but also, on a balanced composition of amino acids. The nutritional value of the maize protein is similar to the other cereals, exhibiting as a rule a deficiency for some essential amino acids (FAO, 1993). Maize seed amino acid profile reveals a deficiency in the essential amino acids lysine, tryptophan and threonine, which was originally demonstrated in studies with animals and humans (Zarkadas et al., 1995). A deficiency in isoleucine was also detected that was attributed to the high leucine concentration which interfers with isoleucine absorption (Benton et al., 1956). Mixing maize and soybean in for- mulations for animal feeding may compensate for deficiencies in lysine and tryptophan, but soybean is deficient in methionine; therefore, selection for higher concentrations of methionine in maize is also desirable (Hacham et al., 2008).

Maize oil is considered of better quality than soybean oil due to the high content $(85 \%)$ of non saturated fatty acids, resulting in better digestibility and a smaller risk of causing vascular problems (Fitch, 1985; Dupont et al., 1990). Additionally, oil has a higher caloric value than starch. Although it is not a nutrient that can be considered deficient in the maize grain, there is a commercial interest in increasing oil concentration. A high oil concentration diet allows a higher gain: feed consumption ratio, as demonstrated for swine (Nordstron et al., 
1972; O'Quinn et al., 2000) and poultry (Han et al., 1987). High-lysine maize has also been shown to have positive effects on broiler chickens (Lucas et al., 2007).

Protein and oil concentrations are quantitative traits and several studies have shown the existence of variability and the possibility of genetic improvement for both traits (Dudley and Lambert, 1992; Misevic and Alexander, 1989; Song et al., 1999). On the other hand, the improvement of protein quality in maize has largely been based on the use of mutant genes that frequently show undesirable pleiotropic effects (Azevedo et al., 2003; Azevedo and Arruda, 2010). The limitations of this strategy, associated with the existence of variability for essential amino acid content and to new faster and efficient techniques of analysis, suggest the use of a quantitative approach in selection.

Variability has been observed for lysine concentration among lines of normal endosperm and among QPM lines, and in hybrids (Moro et al., 1996; Azevedo et al., 2003; Médici, et al., 2009). These results indicate the effectiveness of selection for lysine content in non-opaque maize. And, even Quality Protein Maize (QPM) genotypes may be further selected for higher lysine concentration.

In a Brazilian study with 56 commercial hybrids, significant differences were not observed for lysine concentration in dry matter, varying from 0.25 to $0.27 \%$. On the other hand, threonine concentration varied from 0.24 to $0.36 \%$ and methionine concentration from 0.29 to $0.32 \%$ (Lima et al., 2000). Also, differences among populations for the concentrations of methionine, leucine, isoleucine and valine in percent of the protein were observed (Bressani et al., 1962). The leucine/isoleucine ratio influences the biological use of isoleucine and low values are desirable. Among Brazilian commercial hybrids, leucine concentrations in dry matter varied from 0.65 to $1.54 \%$ and isoleucine concentrations from 0.33 to $0.53 \%$ (Lima et al., 2000). Information about other amino acids is lacking in scientific literature.

It is also important to mention the tremendous recent advances obtained with production of Quality Protein Maize (QPM) lines (Gutierrez-Rojas et al., 2008). The production of transgenic maize lines exhibiting higher levels of essential amino acids such as lysine is now a reality as reported by the Monsanto group (Houmard et al., 2007) and may should also be considered in breeding programs for the selection of maize lines with a more balanced distribution of key nutrients.

The objective of this work was to study grain nutritional quality in ten maize populations, quantifying the variability among populations, the relative importance of environment and the population by environment interaction effects on nutritional traits, and the associations of these traits with each other and with yield.

\section{Material and Methods}

Ten maize populations were evaluated: GO Flint Composite (F), GO Dent Composite (D), GO Yellow Composite (Y), GO White Composite (W), GO Long Ear
Composite (L), GO Thick Ear Composite (T), GN-01, GN-02, GN-03 and GN-04. These populations were developed as heterotic groups. The commercial hybrid G-85 (Novartis Seeds) was used as a control. Populations were evaluated in three environments in the state of São Paulo, Brazil: Anhembi $\left(22^{\circ} 40^{\prime} \mathrm{S}, 48^{\circ} 00^{\prime} \mathrm{W}\right)$ under normal season and off-season planting, and Piracicaba (22 ${ }^{\circ} 42^{\prime} \mathrm{S}$, $\left.47^{\circ} 39^{\prime} \mathrm{W}\right)$ under off-season planting. Experiments were grown in a randomized block design with six replications. Each plot was composed by two rows $4 \mathrm{~m}$ long, spaced $0.9 \mathrm{~m}$ between rows and $0.2 \mathrm{~m}$ between plants.

Ear yield, protein, oil, and the concentration of the amino acids lysine, methionine, threonine, serine, glutamic acid, proline, glycine, alanine, valine, isoleucine, leucine, tyrosine, phenylalanine, histidine, arginine, cystine, and aspartic acid were evaluated. Ear yield was measured as the weight of corn ears, corrected to $13 \%$ water. It was also corrected to the ideal stand of 40 plants per plot, by the covariance method, and transformed to tons per hectare. Samples for chemical analyses were ground in a refrigerated knife mill Knifetec 1095 (Tecator) after the grains have been broken in a disk mill Cemotec 1090 (Tecator). Analyses were made through the methodology of NIR (near infrared reflectance spectroscopy) with calibration curves developed in house. Spectra of the samples were collected in NIRSystems 6500 scanning monochromator (Silver Spring, MD, USA) using NIRS 3 software, version 3.0, from Infrasoft International (ISI, Port Matilda, PA, USA). Samples were placed in small cups $(50 \mathrm{~mm}$ in diameter, $10 \mathrm{~mm}$ depth) with a quartz window of 35 $\mathrm{mm}$ in diameter. Absorbance data were collected as $\log 1 / \mathrm{R}$, from 400 to $2500 \mathrm{~nm}$. Spectra were transformed by taking a first derivative, with a gap of four data points, a segment of eight data points for a first smooth and of one data point for a second smooth (treatment 1,4,4,1 from ISI software). Standard Normal Variate and Detrend transformations were applied to spectra values in order to reduce light scattering effects (ISI, 1992). Methodology used for obtaining calibration curves followed procedures recommended by the Association of Official Analytical Chemists (AOAC, 1995), i.e., dry matter, oven drying at $105^{\circ} \mathrm{C}$ overnight; protein, Kjeldahl method; oil, ether extraction in a Soxhlet extractor; amino acids, liquid chromatography. All values were adjusted to dry matter. Additionally, amino acid concentrations were obtained in percent of total protein. Only calibration curves with cross-validation determination coefficients higher than 0.60 were used. Individual and combined analyses of variance were performed for all the traits.

The quadratic components associated to the effects of environments, populations and population-environment interaction were calculated based on the expected mean squares of the model. Population means were compared by Tukey (0.05). Populations were also compared to the control by $t$ test. Rank correlations among traits were calculated using population means over the three environments. Divergence among populations was cal- 
culated by Euclidean mean distance (d) with standardized data, according to the following expression:

$\mathrm{d}_{\mathrm{ii}}=\sqrt{\frac{\sum\left(\mathrm{x}_{\mathrm{ij}}-\mathrm{x}_{\mathrm{ij}}\right)^{2}}{\mathrm{p}}}$

where $d_{i,}$ is the Euclidean mean distance between genotypes $\mathrm{i}$ and $\mathrm{i}, \mathrm{p}$ is the number of traits considered and $x_{i j}$ and $x_{i, j}$ are the means of the trait $j$ in the treatments $i$ and i', respectively, in standard deviation units.

The relative contribution of the traits to the divergence was estimated according to Singh (1981). The procedures used the program Genes (Cruz, 2001). Cluster analysis was accomplished by the UPGMA method (unweighted pair-group method with arithmetic average), using NTSYS (Rohlf, 1971).

\section{Results and Discussion}

Population-environment interaction was not significant for most of the traits (Table 1). The interaction was significant only for ear yield and tyrosine (TYR) in dry matter basis $(D M)$. Bressani et al. (1962) observed a genotype-environment interaction for protein concentration and all the studied amino acids, including lysine (LYS), methionine (MET), valine (VAL), leucine (LEU), and isoleucine (ILE) on protein basis (PP). However, the environments represented four Latin-American countries, presumably leading to higher climatic and soil differences. Variation among populations was significant for most of the traits, except for alanine (ALA), tyrosine TYR, and phenylalanine (PHE) in PP. Amino acids analysis differed among populations just when they were analyzed in $D M$. This suggests that variation of the amino acid concentrations in the $D M$ should be associated to variation in the total protein.

Environment effects were significant, except for PHE in PP. Among the environmental factors influencing chemical composition of maize grains there are climatic and soil fertility factors (East and Jones, 1920; Andrews et al., 2009; Oikeh, 1998). When population and environment effects were significant, the effect of environments were more important than populations for the following traits: ear yield, oil concentration, ALA, LEU, TYR, PHE in DM and serine (SER), and LEU in PP. For SER and glutamic acid (GLU) in $D M$ there was strong predominance of the effect of populations (Table 2). The set of populations under study here represent a fixed group and the existence of variability among them, with small effect of environment and the population-environment interaction leads to a high confidence in the selection among populations.

Protein concentration varied from 10.51 to $11.58 \%$ whereas oil concentration varied from 4.20 to $4.69 \%$ (Table 3). These values were higher than the mean of all the analyses performed elsewhere (EMBRAPA, 1991), i.e. $8.68 \%$ for protein concentration, and $3.84 \%$ for oil concentration The population GO Flint stood out, showing higher means for protein and oil concentration. Besides, it was included in the group with higher means for most of the amino acids, when considered in $D M$ (Table 3), and sowing an intermediate yield when compared to the other populations.

The means of all individual populations were higher than the control means for protein concentration, oil concentration and most of the amino acids when considered in DM (Table 3). For LEU, nine of the ten populations were higher than the control mean. For SER, GLU and PHE, some populations overcame the control mean. For TYR, all populations had higher means than the control, including when considered in percent of the protein (Table 4). For ear yield, considering the mean of the three environments, most of the populations were similar to the control and the population $\mathrm{GN}-03$ was higher.

Table 1 - Combined analysis of variance for ear weight $\left(\mathrm{EW}, \mathrm{t} \mathrm{ha}^{-1}\right)$, total protein $(\mathrm{TP})$, oil and amino acid contents on a dry matter basis in maize grains.

\begin{tabular}{|c|c|c|c|c|c|c|c|c|c|}
\hline F.V. & EW & $\mathrm{TP}$ & Oil & SER & GLU & ALA & LEU & TYR & PHE \\
\hline Blocks/E & $0.51 \%$ & $0.50 *$ & 0.06 & 0.75 & $23.88 \%$ & 3.94 & $12.09 *$ & $2.15^{*}$ & $2.38 \%$ \\
\hline Environments (E) & $48.15^{*}$ & $1.71 *$ & $3.92 \%$ & $2.09 *$ & $119.26 *$ & $25.25 \%$ & $237.20 \%$ & $16.62 *$ & $6.80 *$ \\
\hline Populations (P) & $1.17 *$ & $0.60 *$ & $0.24 *$ & $2.06 *$ & $67.63 \%$ & $4.83^{*}$ & $24.97 *$ & $1.27 *$ & $2.15 *$ \\
\hline $\mathrm{P} \times \mathrm{E}$ & $0.59 *$ & 0.14 & 0.05 & 0.52 & 11.79 & 3.43 & 5.76 & $0.94 *$ & 1.16 \\
\hline Error & 0.296 & 0.12 & 0.06 & 0.33 & 9.24 & 2.22 & 4.46 & 0.50 & 0.92 \\
\hline Means & 4.03 & 11.09 & 4.42 & 0.52 & 2.13 & 0.87 & 1.21 & 0.32 & 0.53 \\
\hline C.V. & 13.29 & 3.13 & 5.47 & 3.47 & 4.50 & 5.44 & 5.52 & 7.06 & 5.75 \\
\hline $\mathrm{R}_{2}$ & 0.76 & 0.72 & 0.82 & 0.70 & 0.72 & 0.63 & 0.81 & 0.76 & 0.61 \\
\hline$\Phi_{\mathrm{a}}$ & 23.93 & 0.053 & 0.13 & 0.59 & 36.67 & 7.68 & 77.58 & 5.37 & 1.96 \\
\hline$\Phi_{\mathrm{p}}$ & 0.10 & 0.053 & 0.02 & 1.92 & 64.88 & 2.91 & 22.80 & 0.85 & 1.37 \\
\hline$\Phi_{\mathrm{pa}}$ & 0.02 & 0.007 & 0.00 & 0.64 & 8.50 & 4.04 & 4.33 & 1.46 & 0.79 \\
\hline
\end{tabular}

$\mathrm{SER}=$ serine, $\mathrm{GLU}=$ glutamic acid, $\mathrm{ALA}=$ alanine, $\mathrm{LEU}=$ leucine, $\mathrm{TYR}=$ tyrosine and $\mathrm{PHE}=$ phenylalanine. All mean squares and quadratic components multiplied by $10^{-3}$.*Significant by $\mathrm{F}$ test $(\alpha=5 \%) . \Phi_{\mathrm{a}}, \Phi_{\mathrm{p}}$ and $\Phi_{\mathrm{pa}}$ quadratic components associated to environment, populations and population-environment effects. 
Table 2 - Combined analysis of variance for amino acid contents on protein basis in maize grains.

\begin{tabular}{llccccc}
\hline F.V. & SER & GLU & ALA & LEU & TYR & PHE \\
\hline Blocks/E & 0.29 & 11.22 & 2.32 & 24.72 & $5.89 *$ & 3.64 \\
Environments (E) & $9.19 *$ & $189.01 *$ & $112.37 *$ & $934.00 *$ & $72.92^{*}$ & 3.92 \\
Populations (P) & $1.08^{*}$ & $64.36^{*}$ & 7.15 & 58.99 & 1.82 & 3.06 \\
P $\times$ E & 0.61 & 9.19 & 9.66 & 11.67 & 2.95 & 1.63 \\
Error & 0.46 & 12.81 & 9.81 & 15.52 & 1.63 & 3.96 \\
\hline Means & 4.74 & 19.24 & 7.81 & 10.89 & 2.86 & 4.76 \\
C.V. & 1.44 & 1.86 & 4.01 & 3.62 & 4.46 & 4.18 \\
$\mathrm{R}_{2}$ & 0.66 & 0.66 & 0.52 & 0.80 & 0.78 & 0.64 \\
\hline$\Phi_{\mathrm{a}}$ & 0.29 & 5.87 & 3.42 & 30.62 & 2.38 & 0.00 \\
$\Phi_{\mathrm{p}}$ & 0.07 & 5.73 & -0.30 & 4.83 & 0.02 & -0.10 \\
$\Phi_{\mathrm{pa}}$ & 0.05 & -1.21 & -0.05 & -1.28 & 0.44 & -0.78 \\
\hline
\end{tabular}

$\mathrm{SER}=$ serine, $\mathrm{GLU}=$ glutamic acid, $\mathrm{ALA}=$ alanine, $\mathrm{LEU}=$ leucine, $\mathrm{TYR}=$ tyrosine and $\mathrm{PHE}=$ phenylalanine. All mean squares and quadratic components multiplied by $10^{-3}$. *Significant by $\mathrm{F}$ test $(\alpha=5 \%) . \Phi_{\mathrm{a}}, \Phi_{\mathrm{p}}$ and $\Phi_{\mathrm{pa}}$ quadratic components associated to environment, populations and population-environment effects.

Table 3 - Population means for ear weight $\left(\mathrm{EW}, \mathrm{t} \mathrm{ha}^{-1}\right)$, total protein (TP), oil and amino acid contents on a dry matter basis in maize grains.

\begin{tabular}{|c|c|c|c|c|c|c|c|c|c|}
\hline Genotype & EW & $\mathrm{TP}$ & Oil & SER & GLU & ALA & LEU & TYR & PHE \\
\hline GO Thick ear & $5.88 \mathrm{ab}$ & $10.89 c^{*}$ & $4.28 \mathrm{bc}^{*}$ & $5.11 c^{*}$ & $20.68 b^{*}$ & $8.50 a^{*}$ & $11.97 \mathrm{abcd}^{*}$ & $3.17 \mathrm{ab}^{*}$ & $5.28 a^{*}$ \\
\hline GO Long ear & $5.14 b^{*} *$ & $11.03 b^{* *}$ & $4.20 c^{*}$ & $5.21 \mathrm{bc}^{*}$ & $21.24 b^{*}$ & $8.68 \mathrm{a}^{*}$ & $12.29 \mathrm{abcd} *$ & $3.17 \mathrm{ab}^{*}$ & $5.20 \mathrm{a}^{*}$ \\
\hline GO Dent & $5.89 \mathrm{ab}$ & $11.20 \mathrm{ac}^{*}$ & $4.27 \mathrm{bc}^{*}$ & $5.28 \mathrm{bc}^{*}$ & $21.44 a b^{*}$ & $8.92 a^{*}$ & $12.33 \mathrm{abc}^{*}$ & $3.29 \mathrm{ab}^{*}$ & $5.31 \mathrm{a}^{*}$ \\
\hline GO Flint & $5.43 \mathrm{abc}$ & $11.58 a^{*}$ & $4.69 a^{*}$ & $5.58 a^{*}$ & $22.90 a^{*}$ & $9.06 a^{*}$ & $12.78 \mathrm{ab}^{*}$ & $3.42 a^{*}$ & $5.54 a^{*}$ \\
\hline GO White & $5.51 \mathrm{abc}$ & $11.50 \mathrm{ab}^{*}$ & $4.40 \mathrm{abc}^{*}$ & $5.47 \mathrm{ab}^{*}$ & $22.79 a^{*}$ & $8.90 a^{*}$ & $13.01 \mathrm{a}^{*}$ & $3.30 \mathrm{ab}^{*}$ & $5.54 a^{*}$ \\
\hline GO Yellow & $5.37 \mathrm{abc}$ & $11.19 \mathrm{abc}^{*}$ & $4.55 \mathrm{a}^{*}$ & $5.34 \mathrm{abc}^{*}$ & $21.56 \mathrm{ab}^{*}$ & $8.57 a^{*}$ & $11.83 \mathrm{bcd}^{*}$ & $3.09 \mathrm{ab}^{*}$ & $5.23 \mathrm{a}^{*}$ \\
\hline GN-01 & $5.04 c^{*}$ & $10.85 c^{*}$ & $4.49 \mathrm{abc}^{*}$ & $5.10 c^{*}$ & $20.41 b^{*}$ & $8.40 a^{*}$ & $11.49 \mathrm{~cd}^{*}$ & $3.11 \mathrm{ab}^{*}$ & $5.06 a^{*}$ \\
\hline GN-02 & $5.67 \mathrm{abc}$ & $10.93 b^{*}$ & $4.30 \mathrm{abc}^{*}$ & $5.11 c^{*}$ & $20.79 b^{*}$ & $8.53 \mathrm{a}^{*}$ & 11.94 bcd* & $3.13 \mathrm{ab}^{*}$ & $5.25 a^{*}$ \\
\hline$\Gamma \mathrm{N}-03$ & $6.09 a^{*}$ & $10.81 c^{*}$ & $4.62 \mathrm{a}^{*}$ & $5.16 c^{*}$ & $20.58 \mathrm{~b}^{*}$ & $8.34 \mathrm{a}^{*}$ & $11.23 \mathrm{~d}$ & $3.01 b^{*}$ & $5.11 a^{*}$ \\
\hline$\Gamma \mathrm{N}-04$ & $5.92 \mathrm{ab}$ & $10.94 b^{*}$ & $4.39 \mathrm{bc}^{*}$ & $5.22 \mathrm{bc}^{*}$ & $21.04 b^{*}$ & $8.67 a^{*}$ & $11.88 \mathrm{bcd}^{*}$ & $3.10 \mathrm{ab}^{*}$ & $5.30 \mathrm{a}^{*}$ \\
\hline$\Gamma-85$ & 5.67 & 9.64 & 3.92 & 4.50 & 18.32 & 7.79 & 10.66 & 2.49 & 4.43 \\
\hline
\end{tabular}

$\mathrm{SER}=$ serine, $\mathrm{GLU}=$ glutamic acid, $\mathrm{ALA}=$ alanine $\mathrm{LEU}=$ leucine, $\mathrm{TYR}=$ tyrosine and $\mathrm{PHE}=$ phenylalanine. Means followed by the same letter do not differ by Tukey test $(\alpha=0.05)$. All values multiplied by $10^{-1} \cdot G O=G O$ Composite

Table 4 - Population means for amino acid contents on a protein basis in maize grains.

\begin{tabular}{|c|c|c|c|c|c|c|}
\hline Genotype & SER & GLU & ALA & LEU & TYR & PHE \\
\hline GO Thick ear & $4.70 \mathrm{a}$ & $18.99 \mathrm{bc}$ & $7.80 \mathrm{a}$ & $10.98 \mathrm{abc}$ & $2.91 \mathrm{a}^{*}$ & $4.81 \mathrm{a}^{*}$ \\
\hline GO Long ear & $4.73 \mathrm{a}$ & $19.26 \mathrm{abc}$ & $7.87 \mathrm{a}$ & $11.13 \mathrm{ab}$ & $2.86 a^{*}$ & $4.71 \mathrm{a}$ \\
\hline GO Dent & $4.71 \mathrm{a}$ & $19.14 \mathrm{bc}$ & $7.97 \mathrm{a}$ & $11.00 \mathrm{abc}$ & $2.93 \mathrm{a}^{*}$ & $4.74 \mathrm{a}$ \\
\hline GO Flint & $4.80 a^{*}$ & $19.53 \mathrm{ab}^{*}$ & $7.73 a^{*}$ & $10.97 \mathrm{abc}$ & $2.89 a^{* *}$ & $4.73 \mathrm{a}$ \\
\hline GO White & $4.75 \mathrm{a}^{*}$ & $19.82 a^{*}$ & $7.74 a^{*}$ & $11.31 \mathrm{a}$ & $2.86 a^{*}$ & $4.82 a^{*}$ \\
\hline GO Yellow & $4.79 \mathrm{a}^{*}$ & $19.33 \mathrm{abc}$ & $7.69 a^{* *}$ & $10.60 \mathrm{bc}$ & $2.76 a^{*}$ & $4.70 \mathrm{a}$ \\
\hline GN-01 & $4.71 \mathrm{a}$ & $18.85 \mathrm{c}$ & $7.76 a^{*}$ & $10.61 \mathrm{bc}$ & $2.87 a^{*}$ & $4.67 \mathrm{a}$ \\
\hline GN-02 & $4.71 \mathrm{a}$ & $19.19 \mathrm{bc}$ & $7.84 \mathrm{a}$ & $11.05 \mathrm{ab}$ & $2.90 a^{*}$ & $4.83 a^{*}$ \\
\hline$\Gamma \mathrm{N}-03$ & $4.77 a^{*}$ & $19.02 \mathrm{bc}$ & $7.71 a^{*}$ & $10.37 c^{*}$ & $2.78 a^{*}$ & $4.72 \mathrm{a}$ \\
\hline$\Gamma \mathrm{N}-04$ & $4.77 a^{*}$ & $19.23 \mathrm{bc}$ & $7.93 \mathrm{a}$ & $10.84 \mathrm{abc}$ & $2.82 a^{* *}$ & $4.85 a^{*}$ \\
\hline$\Gamma-85$ & 4.68 & 19.01 & 8.08 & 11.03 & 2.56 & 4.59 \\
\hline
\end{tabular}

$\mathrm{SER}=$ serine, $\mathrm{GLU}=$ glutamic acid, $\mathrm{ALA}=$ alanine, $\mathrm{LEU}=$ leucine, $\mathrm{TYR}=$ tyrosine and $\mathrm{PHE}=$ phenylalanine. Means followed by the same letter do not differ by Tukey test $(\alpha=0.05)$. All values multiplied by $10^{-1}$. $\mathrm{GO}=\mathrm{GO}$ Composite. 
No associations between protein and oil concentration were found (Table 5). In the same way, there was no association between ear yield and the other traits in each environment (data not shown). Negative correlations have been detected between grain yield and protein concentration (Corcuera and Naranjo, 1995; Dudley and Lambert, 1992). In the same way, some authors show the existence of negative correlations between oil concentration and yield. However, Alexander and Lambert (1968) concluded that the capacity of the plant to produce carbohydrates and synthesize oil is physiologically independent in the interval from 4 to $7 \%$ oil. Dorsey-Redding et al. (1991) and Séne et al. (2001) did not detect association between protein concentration and oil concentration, although other authors have obtained positive correlations and, in some cases, of high value (Song et al., 1999).

The amino acids SER, GLU, ALA, LEU, TYR and PHE in $D M$ were positively correlated to protein concentration (Table 5). These correlations were high, varying from 0.72 to 0.98 , indicating a proportional increase in the concentrations of those amino acids with an increase in protein concentration. Considering the amino acids in PP, only GLU was positively correlated to the protein concentration. On the other hand, the amino acid LEU, whose proportion must be reduced, was independent from protein concentration. Such a result indicates that there would not be additional difficulty to select these traits simultaneously with protein concen-

Table 5 - Spearman correlations among total protein (TP) and oil, and amino acid contents as dry matter percent and as percent of the protein. Means of three environments, Piracicaba, Brazil, 1998/99.

\begin{tabular}{llc}
\hline Traits & TP & Oil \\
\hline \% of dry matter & & \\
\hline TP & - & \\
Oil & 0.03 & - \\
\hline SER & $0.90^{*}$ & 0.30 \\
GLU & $0.98^{*}$ & 0.13 \\
ALA & $0.95^{*}$ & -0.14 \\
LEU & $0.82^{*}$ & -0.30 \\
TYR & $0.72 *$ & -0.22 \\
PHE & $0.79 *$ & 0.01 \\
\hline \% of total protein & & \\
SER & 0.49 & $0.65^{*}$ \\
GLU & $0.83 *$ & 0.20 \\
ALA & 0.02 & $-0.83^{*}$ \\
LEU & 0.47 & $-0.65^{*}$ \\
TYR & 0.14 & -0.44 \\
PHE & 0.15 & -0.28 \\
\hline SER & & \\
\hline
\end{tabular}

SER $=$ serine, $\quad \mathrm{GLU}=$ glutamic acid, $\mathrm{ALA}=$ alanine, $\mathrm{LEU}=$ leucine, $\mathrm{TYR}=$ tyrosine and $\mathrm{PHE}=$ phenylalanine. $*$ Significant at $5 \%$ probability tration. Yet, considering the amino acids in PP, SER was positively correlated with oil concentration, while ALA and LEU were negatively correlated to it.

Four groups of genotypes were identified based on Euclidean mean distance (d) (Figure 1). The lowest value of $\mathrm{d}$ occurred between populations GO Thick Ear and GN-02 (0.32) and the highest value was between GO White and GN-03 (2.62). Group I was formed by the populations GO Thick Ear, GO Long Ear, GO Dent, GN-01 and GN-02. Group II was formed by the populations GO Yellow and GN-04. Group III contained populations GO Flint and GO White and group IV the population GN-03 (Figure 1).

Although showing the smallest distance, populations GN-02 and GO Thick Ear are not related to each other. Populations GN-01 and GN-02 were identified as belonging to the same group, although they have been developed as complementary heterotic groups (Nass and Miranda Filho, 1999). However, the choice of genotypes to the formation of these populations was based in agronomic traits, mainly grain yield (Naspolini Filho et al., 1981; Santos et al., 1994), and no attention was given to nutritional quality.

Considering the methodology used for the development of GO populations - visual selection of ears with contrasting phenotype - a higher contrast was expected in the combinations of GO Flint with Dent, Yellow with White and Long Ear with Thick Ear than in the other combinations. In the first two cases, populations were placed in separate groups, with $\mathrm{d}$ equal to 1.36 and 1.47, respectively. However, populations GO Long Ear and GO Thick Ear were clustered in the same group and the distance among them was equal to 0.74 . In a similar way to what was discussed for the GN composites, the criterion used to the formation of these populations was not based on nutritional quality. The described results suggest that grain texture and color used as criteria to differentiate the populations GO Flint and Dent and GO Yellow e White, respectively,

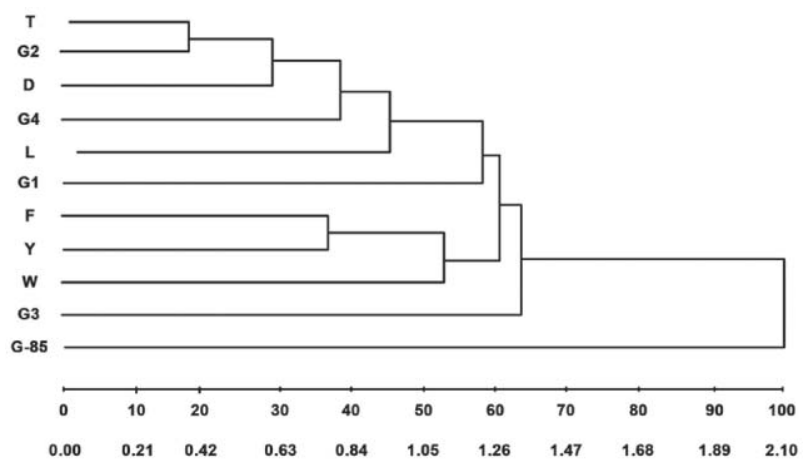

Figure 1 - Dendogram based on Euclidean mean distances, Piracicaba, Brazil, 1998/99. Cophenetic correlation $\mathrm{r}=0.83 . \mathrm{F}=\mathrm{GO}$ Flint Composite, $\mathrm{D}=\mathrm{GO}$ Dent Composite, $\mathrm{Y}=\mathrm{GO}$ Yellow Composite, $\mathrm{W}=\mathrm{GO}$ White Composite, L=GO Long Ear Composite, $\mathrm{T}=\mathrm{GO}$ Thick Ear Composite, G1=GN-01, $\mathrm{G} 2=\mathrm{GN}-02, \mathrm{G} 3=\mathrm{GN}-03$ and $\mathrm{G} 4=\mathrm{GN}-04$. 
are associated to the chemical composition of maize grain, while the diameter and length of the ear, used to differentiate GO Long Ear and GO Thick Ear, are not related to it.

\section{Conclusions}

Populations diverge for most of the traits, indicating the possibility of selection of genotypes with better nutritional quality. Environmental effects influence variation for most of the traits, unlike genotype-environment interaction, allowing the selection on the average of environments. Positive association exists among protein and most of the amino acids, when considered in a dry matter basis. There is no association between nutritional quality and yield; therefore, the development of cultivars that are superior for both traits is expected to be feasible.

\section{References}

Alexander, D.E.; Lambert, R.J. 1968. Relationship of kernel oil content to yield in maize. Crop Science 8: 273-274.

Andrews, M.; Lea, P.J.; Raven, J.A.; Azevedo, R.A. 2009. Nitrogen use efficiency. 3. Nitrogen fixation: gene and costs. Annals of Applied Biology 155: 1-13.

Association of Official Analytical Chemists [AOAC]. 1995. Official methods of analysis of AOAC International. 16ed. AOAC, Washington, DC, USA.

Azevedo, R.A.; Arruda, P. 2010. High-lysine maize: the key discoveries that have made it possible. Amino Acids 39: 979989.

Azevedo, R.A.; Damerval, C.; Landry, J.; Lea, P.J.; Bellato, C.M.; Meinhardt, L.W.; Le Guilloux, M.; Delhaye, S.; Toro, A.A.; Gaziola, S.A.; Berdejo, D.B.A. 2003. Regulation of maize lysine metabolism and endosperm protein synthesis by opaque and floury mutations. European Journal of Biochemistry 270: 48984908.

Benton, D.A.; Harper, A.E.; Spivey, H.E.; Elvehjem, C.A. 1956. Leucine, isoleucine and valine relationships in the rat. Archives of Biochemistry and Biophysics 60: 147-155.

Bressani, R.; Elías, L.G.; Scrimshaw, N.S.; Guzmán, M.A. 1962. Nutritive value of Central American corns. VI. Varietal and environment influence of the nitrogen, essential amino acid, and fat content of ten varieties. Cereal Chemistry 39: 59-67.

Corcuera, V.R.; Naranjo, C.A. 1995. Inheritance of protein content in the endosperm. Maize Genetics Cooperation Newsletter 69: 125.

Cruz, C.D. 2001. GENES Program for Windows: Genetics and Statistics Software. UFV, Viçosa, MG, Brazil. (in Portuguese).

Dorsey-Redding, C.D.; Hurburgh Jr., C.R.; Johnson, L.A.; Fox, S.R. 1991. Relationships among maize quality factors. Cereal Chemistry 68: 602-605.

Dudley, J.W.; Lambert, R.J. 1992. Ninety generations of selection for oil and protein in maize. Maydica 37: 81-87.

Dupont, J.; White, P.J.; Carpenter, M.P.; Schaefer, E.J.; Meydani, S.N.; Elson, C.E.; Woods, M.; Gorbach, S.L. 1990. Journal of the American College of Nutrition 9: 438-470.

East, E.M.; Jones, D.F. 1920. Genetic studies on the protein content of maize. Genetics 5: 543-610.

Empresa Brasileira de Pesquisa Agropecuária [EMBRAPA]. 1991. Table of Chemical Composition and Energetic Value of Swine and Poultry Feed. Embrapa Swine and Poultry, Concórdia, SC, Brazil. (Documents, 19) (in Portuguese).

Fitch, B. 1985. Corn oil. Journal of the American Oil Chemistry Society 62: 1524-1527.
Food and Agriculture Organization [FAO]. 1993. Maize in Human Nutrition. FAO, Roma, Italy. (FAO Food and Nutrition Series, $35 / 1)$.

Gutierrez-Rojas, A.; Paul-Scott, M.; Leyva, O.R.; Menz, M.; Betrán, J. 2008. Phenotypic characterization of quality protein maize endosperm modification and amino acid contents in a segregating recombinant inbred population. Crop Science 48: 1714-1722.

Hacham, Y.; Matityahu, I.; Schuster, G.; Amir, R. 2008. Overexpression of mutated forms of aspartate kinase and cystathionine gamma-synthase in tobacco leaves resulted in the high accumulation of methionine and threonine. Plant Journal 54: 260-271.

Han, Y., Parsons, C.M.; Alexander, D.E. 1987. Nutritive value of high-oil corn for poultry. Poultry Science 66: 103-111.

Houmard, N.M.; Mainville, J.L.; Bonin, C.P.; Huang, S.; Luethy, M.H.; Malvar, T.M. 2007. High-lysine corn generated by endosperm-specific suppression oflysine catabolism using RNAi. Plant Biotechnology Journal 5:605-614

Infrasoft International [ISI]. 1992. NIRS 3: Routine Operation, Calibration and Network System Management Software for Near Infrared Instruments. ISI, Silver Spring, MD, USA.

Lima, G.J.M.M.; Nones, K.; Klein, C.H.; Bellaver, C.; Zanotto, D.L.; Brum, A.R.; Pereira, L.R. 2000. Chemical composition of maize commercial hybrids, year 1999/2000. p. 83-192. In: Sorghum Annual Meeting, 28., Maize Annual Meeting, 45. Embrapa/CPACT, Pelotas, RS, Brazil. (in Portuguese).

Lucas D.M.; Taylor, M.L.; Hartnell, G.F.; Nemeth, M.A.; Glenn, K.C.; Davis, S.W. 2007. Broiler performance and carcass characteristics when fed diets containing lysine maize (LY038 or LY038 9 MON 810), control, or Conventional Reference Maize. Poultry Science 86: 2152-2161.

Médici, L.O.; Gaziola, A.S.; Varisi, V.A.; Paula, J.A.C.; Ferreira, R.R.; Azevedo, R.A. 2009. Diallelic analysis for lysine and oil contents in maize grains. Scientia Agricola 66: 204-209.

Misevic, D.; Alexander, D.E. 1989. Twenty-four cycles of phenotypic recurrent selection for percent oil in maize. I. Per se and test-cross performance. Crop Science 29: 320-324.

Moro, G., Habben, J.E.; Hamaker, B.R.; Larkins, B.A. 1996. Characterization of the variability in lysine content for normal and opaque-2 maize endosperm. Crop Science 36: 1651-1659.

Naspolini Filho, V.; Gama, E.E.G.; Vianna, R.T.; Moro, J.R. 1981. General and specific combining ability for yield in a diallel cross among 18 maize populations (Zea mays L.). Revista Brasileira de Genética 4: 571-577.

Nass, L.L.; Miranda Filho, J.B. 1999. Synthesis of new composites of maize (Zea mays L.) for population improvement in Brazil. p. 309-318. In: Reunión Latino Americana del Maíz, 18..Embrapa Milho e Sorgo, Sete Lagoas, MG, Brazil.

Nordstron, J.W., Behrends, B.R.; Meade, R.J.; Thompson, E.H. 1972. Effects of feeding high oil corns to grow-finishing swine. Journal of American Science 35: 357.

Oikeh, S.O.; Kling, J.G.; Okoruwa, A.E. 1998. Nitrogen fertilizer management effects on maize grain quality in the West African moist Savanna. Crop Science 38: 1056-1161.

O'Quinn, P.R.; Nelssen, J.L.; Goodband, R.D.; Knabe, D.A.; Woodworth, J.C.; Tokach, M.D.; Lohrmann, T.T. 2000. Nutritional value of a genetically improved high-lysine, highoil corn for young pigs. Journal of Animal Science 78: 21442149.

Paulis, J.W.; Wall, J.S.; Sanderson, J. 1978. Origin of high methionine content in sugary- 1 corn endosperm. Cereal Chemistry 55: 705712.

Rohlf, F.J.; Augh, J.K.; Kirk, D. 1971. NTSYS: Numerical Taxonomy System of Multivariate Statistical Programs. State University, Stony Brook, NY, USA. (Technical Reports).

Santos, M.X.; Pacheco, C.A.P.; Guimarães, P.E.O.; Gama, E.E.G., Silva, A.E.; Oliveira, A.C. 1994. Diallel among twenty-eight varieties of maize. Revista Brasileira de Genética 17: 277-282. 
Séne, M., Thévenot, C.; Hoffmann, D.; Bénétrix, F.; Causse, M.; Prioul, J.L. 2001. QTLs for grain dry-milling properties, composition and vitreousness in maize recombinant inbred lines. Theoretical and Applied Genetics 102: 591-599.

Singh, D. 1981. The relative importance of characters affecting genetic divergence. The Indian Journal of Genetics and Plant Breeding, 41: 237-245.

Song, T.M.; Kong, F.; Li, C.J.; Song, G.H. 1999. Eleven cycles of single kernel phenotypic recurrent selection for percent oil in Zhongzong no. 2 maize synthetic. Journal of Genetics and Breeding 53: 31-35.
Zarkadas, C.G.; Yu, Z.; Hamilton, H.I.; Pattison, L.; Rose, L.W. 1995. Comparison between the protein quality of northern adapted cultivars of common maize and quality protein maize. Journal of Agricultural of Food Chemistry 43: 84-93.

Received September 11, 2009

Accepted July 14, 2010 